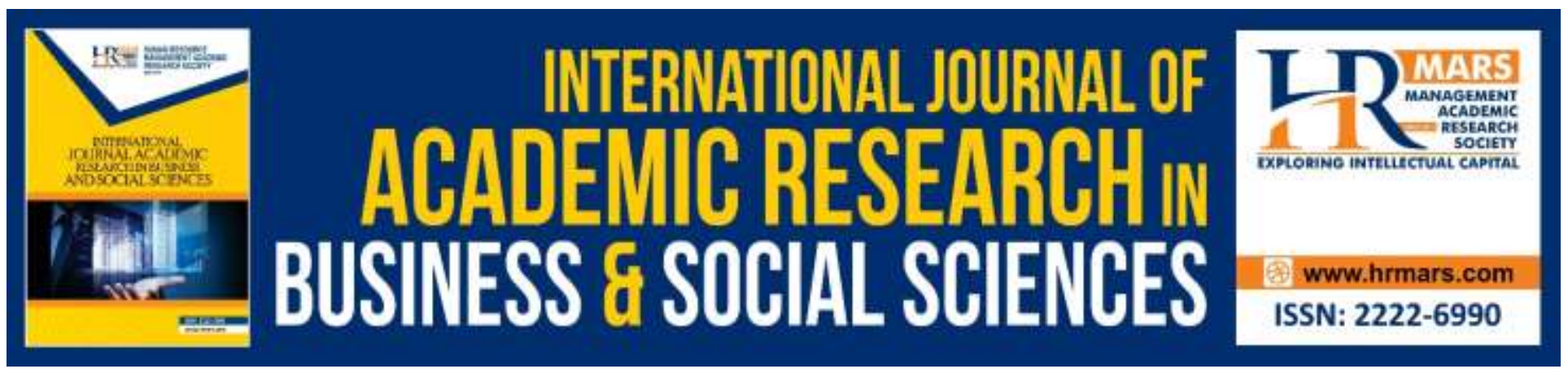

\title{
Validity and Reliability of MEQI-C Item Using Rasch Measurement Model
}

\author{
Noor Haslinda Shuib, Salleh Amat, Dharatun Nissa Puad Mohd Kari, Noriah \\ Mohd Ishak \& Ismail Ahmad
}

To Link this Article: http://dx.doi.org/10.6007/IJARBSS/v10-i4/7148

DOI:10.6007/IJARBSS/v10-i4/7148

Received: 10 February 2020, Revised: 12 March 2020, Accepted: 27 March 2020

Published Online: 24 April 2020

In-Text Citation: (Shuib et al., 2020)

To Cite this Article: Shuib, N. H., Amat, S., Kari, D. N. P. M., Ishak, N. M., \& Ahmad, I. (2020). Validity and Reliability of MEQI-C Item Using Rasch Measurement Model. International Journal of Academic in Research Business and Social Sciences, 10(4), 468-481.

Copyright: (c) 2020 The Author(s)

Published by Human Resource Management Academic Research Society (www.hrmars.com)

This article is published under the Creative Commons Attribution (CC BY 4.0) license. Anyone may reproduce, distribute, translate and create derivative works of this article (for both commercial and non-commercial purposes), subject to full attribution to the original publication and authors. The full terms of this license may be seen at: http://creativecommons.org/licences/by/4.0/legalcode

Vol. 10, No. 4, 2020, Pg. 468 - 481

Full Terms \& Conditions of access and use can be found at http://hrmars.com/index.php/pages/detail/publication-ethics 


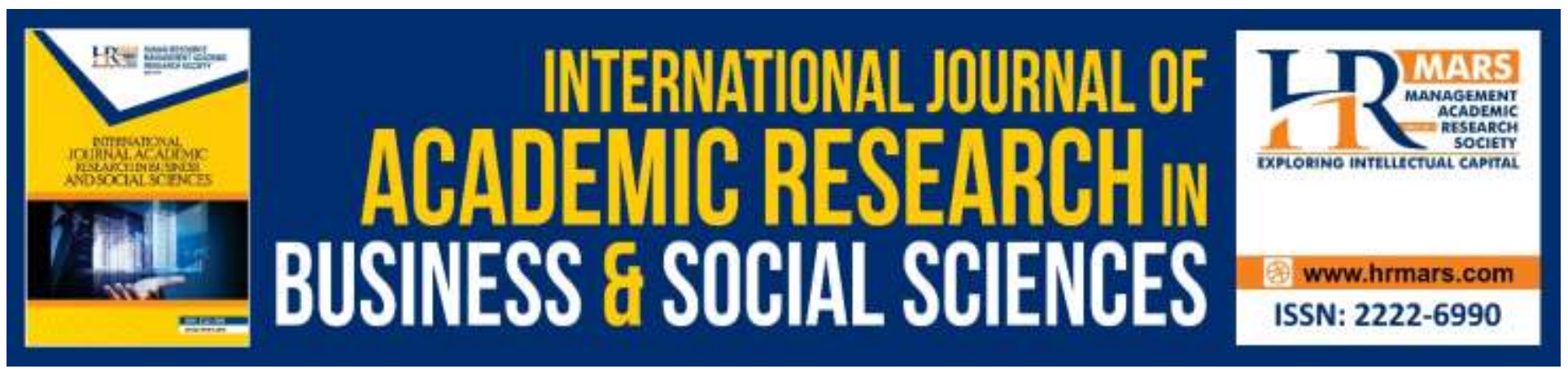

\title{
Validity and Reliability of MEQI-C Item Using Rasch Measurement Model
}

\author{
Noor Haslinda Shuib ${ }^{1,2}$, Salleh Amat ${ }^{2,3}$, Dharatun Nissa Puad Mohd \\ Kari' $^{2}$, Noriah Mohd Ishak ${ }^{2} \&$ Ismail Ahmad ${ }^{2}$ \\ Institute of Teacher Education Technical Education Campus, 71760 Nilai, Negeri Sembilan, \\ Malaysia $^{1}$, Faculty of Education, National University of Malaysia, 43600 Bangi, Selangor, Malaysia ${ }^{2}$ \\ ${ }^{3}$ Email - sallehba@ukm.edu.my
}

\begin{abstract}
Emotional intelligence is a mechanism or ability of a children to identify their competence, character and leadership traits towards achieving common goals and a positive self-image. This study was undertaken to produce empirical evidence on the validity and reliability of the Malaysian Emotional Quotient Inventory-Children (MEQI-C) questionnaire. Data were analyzed using Rasch Model by Winstep software. A total of 356 students from Grade 4 and 5 of a primary school in Seremban, Negeri Sembilan were involved in this study. The results showed that the reliability of the MEQI-C item was high at 0.97, all 30 items measured emotional intelligence constructs, 29 items were retained (item fit) and one item was improved, the MEQI-C questionnaire was consistent with the individual's ability level and the items reached the concept of single unidimensionality. These five diagnoses complied with the requirements needed to examine the validity and reliability of the MEQI-C. It can be concluded that the MEQI-C is valid and reliable to be used in this study.
\end{abstract}

Keywords: Emotional Intelligences, Rasch Measurement Model, Validity, Reliability, Children.

\section{Introduction}

Emotional intelligence is important in developing an individual potential. Emotional intelligence is often associated with those who continue to be successful and excellence in life (Bar-On \& Parker, 2000; Goleman, 1996; 1999; Noriah, 2019). Emotional intelligence is the ability for the individual to recognize, understand, analyze and control his or her emotions and others throughout the daily life, as well as connecting to the surrounding communities. Goleman $(1996,1999)$ summarized various aspects of emotional intelligence which are crucial in shaping an individual personality. There are six essentials of emotional intelligence, namely able to self-motivate, relieve stress, communicate effectively, empathize with others, overcome challenges and resolve conflicts. 
Furthermore, emotional intelligence is defined as the ability to recognize own and other people's feelings, to self-motivate, manage emotions well and communicate effectively with others (Noriah, 2019). The emotional intelligence is divided into two competencies, namely personal competence which controls over one's actions, and social competence which controls over his or her relationship with others. A balanced individual has high emotional intelligence coupled with intellectual as the basis of physical, emotional, spiritual, intellectual and social balance where spiritual intelligence is at its highest. According to Noriah (2019), if social problems can be overcome, then more success in curriculum and co-curriculum can be sustained.

\section{Literature Review}

Basically, the Malaysian Emotional Quotient Inventory-Children (MEQI-C) is a concept of emotional intelligence as suggested by Daniel Goleman in 1996. It consists of five domains, namely selfawareness, self-regulation, self-motivation, empathy and social skills. However, in the local context, studies conducted by Noriah and colleagues since 2002 have shown an increase in two domains of emotional intelligence, namely spiritual awareness and maturity in the MEQI-A. The MEQI-C is an instrument adapted and modified from the adult version of the MEQI-A to the children's version of the MEQI-C by Siti Aishah in year 2006. Then, the MEQI-C was gazetted as the intellectual properties by Siti Aishah in 2008. MEQI-C is an instrument built to be adapted in children's development to measure their level of emotional intelligence.

The domain in the Emotional Intelligence Model of Goleman (1996) is almost identical or perhaps identical after being adapted in the Malaysian context. Self-awareness refers to a person's ability to perceive his or her inner state of emotion or feeling at that moment. The individual uses self-awareness as a guide in making decisions with a realistic self-appraisal, the ability to selfmonitor and self-trust. Self-regulation refers to the self-regulation of an individual's ability to manage emotions and control them when carrying out an assignment so that it is easier and less distracting. Such individuals are also prudent and honest when they take action, which can delay the turbulent emotions in pursuit of the desired goal and quickly recover from emotional stress.

Self-motivation refers to a person's ability to drive his or her behaviour in order to move toward a goal. The individual also uses his or her own will in the form of a whisper of his or her heart to self-guide in taking self-improvement initiatives. The individual is often passionate about achieving goals and excellence. Empathy refers to a person's ability to truly understand others' feelings according to their perceptions. This ability generates internal and external warmth when building relationships. Social skill refers to a person's ability to actively interact with others, either directly or indirectly, over time. Success in communication, self-control, response, recognition and emotional control are the areas which are frequently measured in social skills. These skills allow the individual to control and manage the emotions that are borne in his or her interactions with others as well as able to accurately interpret his or her social and environmental conditions.

Maturity refers to a person's ability to use life experience in solving problems or making decisions correctly. The individual is self-aware of his or her own weaknesses and strengths that can affect emotional stability. Maturity comes with a person's age, experience and knowledge factors. 
INTERNATIONAL JOURNAL OF ACADEMIC RESEARCH IN BUSINESS AND SOCIAL SCIENCES Vol. 10, No. 4, April, 2020, E-ISSN: 2222-6990 @ 2020 HRMARS

This finding is supported by Aishah (2006) that maturity is the ability to use one's life experience to enhance confidence which in turn affects emotional stability. Spiritual awareness refers to a person's feeling toward God that can assist him in maintaining emotional stability (Richardson, 2015). The individual accepts God's requirements by holding the concept of wholeheartedly accepting, self-reflection, remembering Him and adhering to religious guidelines. Accepting wholeheartedly what has been decreed by the God enables one to sincerely accept certain rules set by their religion. Meanwhile, the awareness of responsibility to God helps to perform tasks without fear. This statement is supported by Aishah (2006) that spirituality is a person's feeling towards his Creator and how that feeling helps in maintaining emotional stability.

MEQI-C measurement can be used as an intervention guide to foster emotional intelligence so that children can manage their lives better and capable of overcoming many social problems inherent in the 21st century. According to a study conducted by Aishah (2006), the MEQI-C comprises items that measure intrapersonal, interpersonal, spirituality and maturity competence. Intrapersonal competence comprises four domains, namely self-awareness, self-confidence, selfregulation and self-motivation. Subsequently, interpersonal competence comprises two domains, namely empathy and social skills. Intrapersonal and interpersonal are bidimensional constructs, while spirituality and maturity are single or unidimensional constructs. The detailed discussion of emotional intelligence items found in the MEQI-C is the same as the MEQI-A which is based on the Goleman's Emotional Intelligence model adapted of Noriah in 2004.

According to the literature, the MEQI-C has been tested several times on different samples of primary school students. Aishah (2006) conducted a validation of two pilot studies on MEQI-C and found that MEQI-C met the standards requirements or psychometric characteristics. The study also had used Exploratory Factor Analysis (EFA) to select items that were considered appropriate to measure the constructs studied. The first pilot study of MEQI-C was conducted on 90 students from the Integrated Religious Elementary School aimed at improving the instrument such as the use of sentences based on the level of children. For this phase, 45 items were retained, while items with loading values below 0.3 were dropped as stated by Hair et al. (2006). Several stages were implemented that allowed only 30 items to be retained to collect actual research data.

The second pilot study of MEQI-C was conducted on 200 students of Integrated Religious Elementary School students from the Klang Valley aimed at identifying the reliability, internal consistency and the underlying dimensions of the MEQI-C. The validities of the face and the MEQI-C content were also taken into account in the opinion of experts in this field. The findings showed that the values of loading items received for MEQI-C were; (i) intrapersonal competence for the domain of self-awareness $(E Q 1=.48, E Q 2=.58$ and $E Q 3=.72)$, self-confidence $(E Q 4=.28, E Q 7=$ .69 and $\mathrm{EQ} 8=.65)$ and self-motivation $(\mathrm{EQ9}=.70$, EQ10 $=.62$ and $\mathrm{EQ11}=.37)$; (ii) interpersonal competence for empathy domain (EQ13 =.46, $\mathrm{EQ16}=.61, \mathrm{EQ} 15=.73$ and $\mathrm{EQ} 14=.46)$ and social skills domain (EQ18 = .56, EQ17 = .46 and EQ19 = .66); (iii) spiritual domain (EQ20 = .37, EQ21 = .35, $\mathrm{EQ} 22=.80$ and EQ23 $=.48$ ); and (iv) the maturity domain (EQ26 $=.56, \mathrm{EQ} 27=.71, \mathrm{EQ} 30=.52$ and EQ28 = .60) (Siti Aishah 2006). The findings showed that all domains have high construct validity. 
INTERNATIONAL JOURNAL OF ACADEMIC RESEARCH IN BUSINESS AND SOCIAL SCIENCES Vol. 10, No. 4, April, 2020, E-ISSN: 2222-6990 @ 2020 HRMARS

The MEQI-C has good reliability values and is very suitable for use in local cultural contexts (Siti Aishah 2006). A study conducted by Siti Aishah (2006) for the first MEQI-C pilot showed that Cronbach's alpha was .87; the intrapersonal domain was .77, interpersonal domain was .62 and spiritual and maturity domains were .75. Subsequently, the overall Cronbach's alpha for the second pilot study of the MEQI-C was .71; the intrapersonal domain was .62, interpersonal domain was .77, spiritual domain was .52 and maturity domain was .54 as shown in Table 1.

Table 1 Cronbach's alpha values for each MEQI-C domain

\begin{tabular}{llcccc}
\hline Competence & Domain & $\begin{array}{c}\text { Number } \\
\text { of Items }\end{array}$ & $\begin{array}{c}\text { Alpha } \\
\text { Cronbach } \\
\text { for Pilot 1 }\end{array}$ & $\begin{array}{c}\text { Alpha } \\
\text { Cronbach for } \\
\text { Pilot 2 }\end{array}$ & $\begin{array}{c}\text { Alpha } \\
\text { Cronbach } \\
\text { per item }\end{array}$ \\
\hline Intrapersonal & Self-Awareness & 3 & & & .49 \\
& Self-Regulation & 6 & .77 & .62 & - \\
& Self-Motivation & 3 & & & .85 \\
& Self-Confidence & 3 & & .99 & .96 \\
Interpersonal & Empathy & 4 & .62 & .77 & .70 \\
Spirituality & Social Skill & 3 & & .52 & .80 \\
Maturity & 4 & .75 & .54 & .71 \\
\hline Overall alpha coefficient & $\mathbf{3 0}$ items & .87 & .71 & \\
\hline
\end{tabular}

Although the study conducted by Siti Aishah (2006) found that the MEQI-C has high validity and reliability, but the process has to be carried out again as it involved different study respondents. Thus, in this study the researcher conducted a validity and reliability analysis using Rasch Model to look at it from different perspectives. Besides, in general, validity and reliability are only reflected in the overall Cronbach's alpha of an instrument. However, in this study, Rasch model measurements were used to examine the functionality of each MEQI-C instrument item in depth through several diagnostics to determine its validity and reliability. Therefore, using the Rasch Measurement Model, the objectives of this study are to identify; (1) reliability and separation of items- individual; (2) item polarity; (3) item and individual suitability; (4) difficulty level of the item; and (5) unidimensionality of the MEQI-C items.

\section{Methodology}

The study was conducted using a survey of 356 students from Grade 4 and 5 of a primary school in Seremban, Negeri Sembilan. Male students were 57\% $(n=203)$ and female students were $43 \%(n=$ 153). The sample also comprised $56 \%(n=200)$ of 10 -year-olds and $44 \%(n=156) 11$-year-olds students. The sample size of this study was sufficient to accommodate 30 to 50 people (Fraenkel et al., 2018) or 25 to 100 people (Cooper \& Schindlre, 2011) to test the reliability and validity of a questionnaire. The data of this study were analyzed using Rasch and Winsteps 3.73 measurements. Data collection was conducted through counseling teachers who then distributed the instruments to the students. Students were grouped together in a large hall and were given 40 minutes to response to the instruments. The counseling teachers facilitated the whole process. 
INTERNATIONAL JOURNAL OF ACADEMIC RESEARCH IN BUSINESS AND SOCIAL SCIENCES

Vol. 10, No. 4, April, 2020, E-ISSN: 2222-6990 @ 2020 HRMARS

\section{Research Instrument}

The MEQI-C contained 30 items and formed dichotomous data using correct and incorrect statements. It can be answered using pencil and paper and available in two versions that is in Malay and English Languages. The instrument consisted of two sections which Section 1 covered the profile of respondents such as name, school name, age, class, gender, number of siblings and birth status in family, while Section 2 included statements that measured each domain and subdomain of emotional intelligence. Each MEQI-C item referred to the personal feelings and behaviours of the subject responding to the instrument. There was no right or wrong answer to every statement. The subject's honesty in answering the question determined the reliability of the answers given.

Prior to the actual study, the MEQI-C instrument was tested for face validity by three students of different races from various primary schools nearby. The purpose is to examine their understanding of the questions in the MEQI-C items. This involved accuracy and appropriateness of terms, sentence structure, language adjustments, word clarity and format neatness (Fraenkel et al., 2018).

\section{Results}

\section{Reliability and Separation of Item-Individual of MEQI-C}

Table 2 shows that item reliability was 0.97 with the item separation index of 6.13 . Item and individual reliability can indicate the extent to which items conform to the Rasch model, and item and individual separation index. The separation index showed the number of strata of item difficulty and the individual ability identified in the group studied.

Table 2 Reliability and Separation of MEQI-C Items

INPUT: 293 PERSON 30 ITEM REPORTED: 293 PERSON 30 ITEM 2 CATS WINSTEPS 3.73

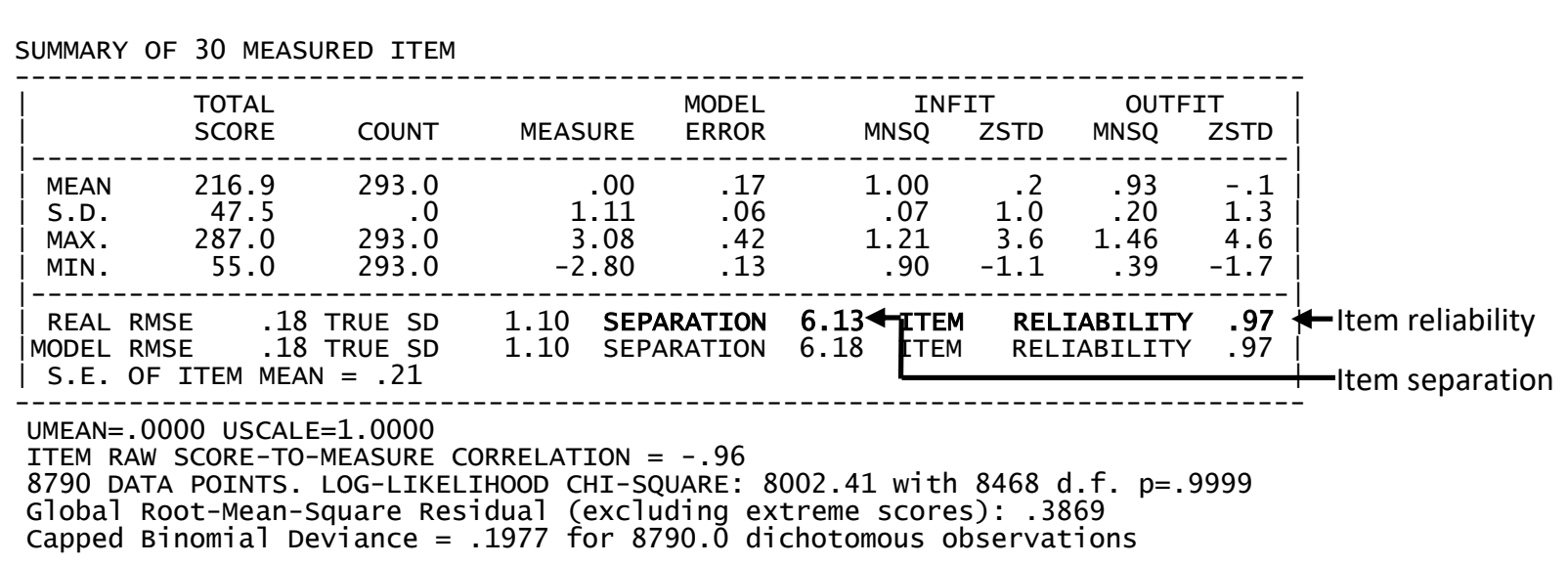

Table 3 shows that the individual reliability was 0.62 with the individual separation index of 1.29. It also shows that Cronbach's alpha of MEQI-C was 0.67. According to Table 4, the Cronbach's alpha reliability index of MEQI-C was good and acceptable (Bond \& Fox, 2007). 
INTERNATIONAL JOURNAL OF ACADEMIC RESEARCH IN BUSINESS AND SOCIAL SCIENCES

Vol. 10, No. 4, April, 2020, E-ISSN: 2222-6990 @ 2020 HRMARS

Table 3 Reliability and Separation of MEQI-C Individuals

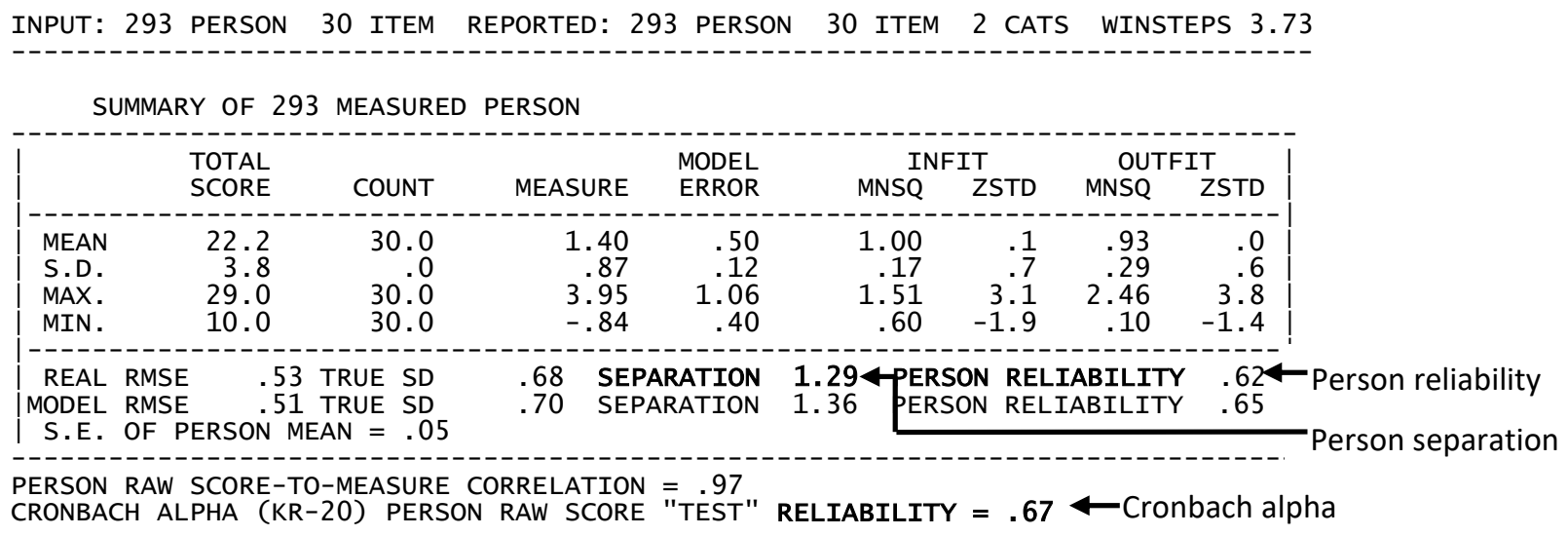

Table 4 Interpretation of Reliability Score (Bond \& Fox, 2007)

\begin{tabular}{ll}
\hline Score & Reliability \\
\hline $0.9-1.0$ & Very good and effective with a high degree of \\
& consistency \\
$0.7-0.8$ & Good and acceptable \\
$0.6-0.7$ & Acceptable \\
$<0.6$ & Item needs modification \\
$<0.5$ & Item needs to be dropped \\
\hline
\end{tabular}

Item Polarity of MEQI-C

Table 5 shows that all of the PTMEA values (point-measure correlation, PTMEA Corr.) or item alignments for all 30 items were positive. Polarity is an early detection or fundamental analysis of construct validity which indicates that the items used move towards the measurement of a single sub construct (Bond \& Fox, 2015). Measurements indicating positive index means that the item measures the construct that it wants to measure and it works in parallel to measure the construct (Linacre, 2005). Moreover, Table 4 shows that it is a productive or a good measure (Linacre, 2005). 
INTERNATIONAL JOURNAL OF ACADEMIC RESEARCH IN BUSINESS AND SOCIAL SCIENCES

Vol. 10, No. 4, April, 2020, E-ISSN: 2222-6990 @ 2020 HRMARS

Table 5 Analysis of Item Polarity of MEQI-C

\begin{tabular}{|c|c|c|c|c|c|c|c|c|c|c|c|c|c|c|}
\hline & $\begin{array}{l}\text { IN } \\
--\end{array}$ & $\begin{array}{r}\text { PUT: } 29 \\
\text { PERSO }\end{array}$ & $\begin{array}{l}\text { PERSON } \\
\mathrm{N}: \text { REAL }\end{array}$ & $\begin{array}{r}30 \text { ITE } \\
\text { SEP.: } 1\end{array}$ & $\begin{array}{ll}1 & \text { REPO } \\
29 & \text { REL } \\
\text { TEM STA }\end{array}$ & ATISTIC & SS: & ITEM: & $\begin{array}{l}\text { REAL } \\
\text { E ORDE }\end{array}$ & $\begin{array}{l}\text { SEM } \\
\text { SEP. : }\end{array}$ & 6.13 & REL. : & .97 & \\
\hline & $\begin{array}{l}\text { ENTRY } \\
\text { NUMBER }\end{array}$ & $\begin{array}{l}\text { TOTAL } \\
\text { SCORE }\end{array}$ & $\begin{array}{l}\text { TOTAL } \\
\text { COUNT }\end{array}$ & MEASURE & $\begin{array}{l}\text { MODEL } \\
\text { S.E. }\end{array}$ & INS & $\begin{array}{l}\text { IT } \\
\text { ZSTD }\end{array}$ & $\begin{array}{c}\text { OUT } \\
\text { MNSQ }\end{array}$ & $\begin{array}{l}\text { FIT } \\
\text { ZSTD }\end{array}$ & $\begin{array}{l}\text { PT-MEA } \\
\text { CORR. }\end{array}$ & $\begin{array}{l}\text { URE } \\
\text { EXP. }\end{array}$ & \begin{tabular}{|} 
EXACT \\
OBS\%
\end{tabular} & $\begin{array}{r}\text { MATCH } \\
\text { EXP\% }\end{array}$ & ITEM \\
\hline Micf & $\begin{array}{r}4 \\
6 \\
5 \\
14 \\
12 \\
19 \\
26 \\
29 \\
1 \\
30 \\
17 \\
27 \\
21 \\
3 \\
10 \\
11 \\
16 \\
25 \\
18 \\
24 \\
28 \\
9 \\
15 \\
2 \\
8 \\
7 \\
13 \\
22 \\
20 \\
23\end{array}$ & $\begin{array}{r}55 \\
128 \\
157 \\
165 \\
166 \\
198 \\
199 \\
199 \\
205 \\
207 \\
211 \\
211 \\
214 \\
215 \\
215 \\
220 \\
220 \\
232 \\
234 \\
235 \\
242 \\
244 \\
253 \\
255 \\
255 \\
256 \\
274 \\
274 \\
280 \\
287\end{array}$ & $\begin{array}{l}293 \\
293 \\
293 \\
293 \\
293 \\
293 \\
293 \\
293 \\
293 \\
293 \\
293 \\
293 \\
293 \\
293 \\
293 \\
293 \\
293 \\
293 \\
293 \\
293 \\
293 \\
293 \\
293 \\
293 \\
293 \\
293 \\
293 \\
293 \\
293 \\
293\end{array}$ & $\begin{array}{r}3.08 \\
1.68 \\
1.22 \\
1.10 \\
1.08 \\
.55 \\
.53 \\
.53 \\
.42 \\
.39 \\
.31 \\
.31 \\
.25 \\
.23 \\
.23 \\
.13 \\
.13 \\
-.13 \\
-.17 \\
-.20 \\
-.37 \\
-.42 \\
-.69 \\
-.75 \\
-.75 \\
-.78 \\
-1.57 \\
-1.57 \\
-1.98 \\
-2.80\end{array}$ & $\begin{array}{l}.16 \\
.13 \\
.13 \\
.13 \\
.13 \\
.13 \\
.13 \\
.13 \\
.14 \\
.14 \\
.14 \\
.14 \\
.14 \\
.14 \\
.14 \\
.14 \\
.14 \\
.15 \\
.15 \\
.15 \\
.16 \\
.16 \\
.18 \\
.18 \\
.18 \\
.18 \\
.24 \\
.24 \\
.29 \\
.42\end{array}$ & $\begin{array}{r}1.07 \\
1.05 \\
1.10 \\
1.05 \\
1.04 \\
1.00 \\
1.05 \\
1.21 \\
1.01 \\
.96 \\
1.01 \\
1.00 \\
1.02 \\
1.04 \\
.93 \\
.92 \\
.94 \\
1.03 \\
1.09 \\
.94 \\
.92 \\
.98 \\
1.01 \\
1.01 \\
.96 \\
.99 \\
.90 \\
.91 \\
.91 \\
.95\end{array}$ & $\begin{array}{r}.7 \\
1.1 \\
2.4 \\
1.1 \\
1.0 \\
.0 \\
.9 \\
3.6 \\
.2 \\
-.7 \\
.1 \\
.1 \\
.3 \\
.6 \\
-1.1 \\
-1.1 \\
-.9 \\
.4 \\
1.0 \\
-.7 \\
-.8 \\
-.2 \\
.1 \\
.1 \\
-.3 \\
-.1 \\
-.5 \\
-.4 \\
-.3 \\
.0\end{array}$ & $\begin{array}{r}1.06 \\
1.02 \\
1.12 \\
1.03 \\
1.03 \\
.98 \\
1.04 \\
1.46 \\
1.07 \\
.90 \\
.92 \\
.98 \\
1.19 \\
.96 \\
.83 \\
.83 \\
.87 \\
.98 \\
1.14 \\
.84 \\
.86 \\
.89 \\
.97 \\
.84 \\
.92 \\
.86 \\
.62 \\
.66 \\
.59 \\
.39\end{array}$ & $\begin{array}{r}.4 \\
.3 \\
1.9 \\
.5 \\
.4 \\
-.2 \\
.5 \\
4.6 \\
.7 \\
-1.0 \\
-.7 \\
-.2 \\
1.7 \\
-.3 \\
-1.7 \\
-1.5 \\
-1.2 \\
-.1 \\
1.0 \\
-1.1 \\
-.9 \\
-.7 \\
-.1 \\
-.8 \\
-.4 \\
-.6 \\
-1.3 \\
-1.2 \\
-1.2 \\
-1.4\end{array}$ & $\begin{array}{l}.26 \\
.32 \\
.25 \\
.31 \\
.32 \\
.34 \\
.29 \\
.07 \\
.32 \\
.38 \\
.33 \\
.32 \\
.28 \\
.29 \\
.41 \\
.41 \\
.39 \\
.27 \\
.19 \\
.37 \\
.37 \\
.31 \\
.25 \\
.27 \\
.30 \\
.29 \\
.34 \\
.31 \\
.29 \\
.24\end{array}$ & $\begin{array}{l}.32 \\
.37 \\
.36 \\
.36 \\
.36 \\
.34 \\
.34 \\
.34 \\
.33 \\
.33 \\
.32 \\
.32 \\
.32 \\
.32 \\
.32 \\
.31 \\
.31 \\
.30 \\
.29 \\
.29 \\
.28 \\
.28 \\
.26 \\
.25 \\
.25 \\
.25 \\
.19 \\
.19 \\
.16 \\
.11\end{array}$ & $\begin{array}{l}79.5 \\
63.8 \\
59.7 \\
60.4 \\
62.8 \\
68.6 \\
66.9 \\
64.8 \\
72.4 \\
73.0 \\
73.0 \\
73.7 \\
72.0 \\
73.0 \\
76.5 \\
77.8 \\
78.5 \\
79.9 \\
79.2 \\
81.6 \\
82.6 \\
82.6 \\
86.3 \\
87.0 \\
87.7 \\
87.4 \\
93.5 \\
93.5 \\
95.6 \\
98.0\end{array}$ & $\begin{array}{l}82.0 \\
65.7 \\
65.0 \\
65.5 \\
65.6 \\
70.6 \\
70.8 \\
70.8 \\
72.3 \\
72.7 \\
73.7 \\
73.7 \\
74.6 \\
74.8 \\
74.8 \\
76.2 \\
76.2 \\
79.8 \\
80.4 \\
80.8 \\
83.0 \\
83.6 \\
86.5 \\
87.1 \\
87.1 \\
87.4 \\
93.5 \\
93.5 \\
95.6 \\
98.0\end{array}$ & $\begin{array}{l}\text { B4 } \\
\text { B6 } \\
\text { B5 } \\
\text { B14 } \\
\text { B12 } \\
\text { B19 } \\
\text { B26 } \\
\text { B29 } \\
\text { B1 } \\
\text { B30 } \\
\text { B17 } \\
\text { B27 } \\
\text { B21 } \\
\text { B3 } \\
\text { B10 } \\
\text { B11 } \\
\text { B16 } \\
\text { B25 } \\
\text { B18 } \\
\text { B24 } \\
\text { B28 } \\
\text { B9 } \\
\text { B15 } \\
\text { B2 } \\
\text { B8 } \\
\text { B7 } \\
\text { B13 } \\
\text { B22 } \\
\text { B20 } \\
\text { B23 }\end{array}$ \\
\hline & $\begin{array}{l}\text { MEAN } \\
\text { S.D. }\end{array}$ & $\begin{array}{r}216.9 \\
47.5\end{array}$ & $\begin{array}{r}293.0 \\
.0\end{array}$ & $\begin{array}{r}.00 \\
1.11\end{array}$ & \begin{tabular}{|l|}
.17 \\
.06
\end{tabular} & $\begin{array}{r}1.00 \\
.07\end{array}$ & & $\begin{array}{l}.93 \\
.20\end{array}$ & $-.1 \mid$ & & & $\begin{array}{l}77.7 \\
10.3\end{array}$ & $\begin{array}{r}78.7 \\
9.1\end{array}$ & \\
\hline
\end{tabular}

\section{Item and Individual Suitability of MEQI-C}

Based on Table 5, this study shows that the range of infit MNSQ item was between 0.90 to 1.21 logit. Infit is an index of the individual's sensitivity responsiveness to the item response pattern, which is the quality of the item used by the majority of respondents. Table 4 also shows that the MNSQ item ranged between 0.59 to 1.46 logit. Outfit is an index of sensitivity towards items which are too easy or too difficult to be agreed by respondents. The acceptable range for MNSQ statistics for dichotomous items is 0.5 to 1.5 logit (Linacre, 2005). The index of both MNSQ Infit and MNSQ Outfit should be taken into account in determining the suitability of the item or fit of item that measures a construct. The item and individual suitability analysis can show the extent to which the accuracy or predictability of the data matches the model.

In determining the number of items that could be retained, it was found that only 29 of the 30 items were within the range of between 0.5 to 1.5 logit. The other item was categorized as a misfit because it was out of range due to the presence of item interruptions (Azrilah, Mohd Saidfudin \& Azami, 2017). The misfit item was B23 as it showed an MNSQ outfit range index of 0.39 
logit, despite having an infit index of 0.95 logit. A value of less than 0.5 logit indicates that the item may be overly predictable and expected by the respondents or it may be that item B23 was away from the study. Linacre (2005) also explained that there may be redundancy with other items or misleading items.

Therefore, item B23 was modified to make the purpose of the question clearer. The researcher changed the item of "I am sure Allah will help diligent people" to "I am sure God will help diligent people (example: study, prayer etc.)" before the questionnaire was distributed in the actual study. In addition, two experts have confirmed that the item was acceptable and remained because it is appropriate to measure the construct that needs to be measured. Aspects of language use, clarity of meaning and appropriateness in the field study were also investigated. As a result, 29 MEQI-C items were retained, while one MEQI-C item was improved.

Furthermore, person fit analysis can help the researcher to identify the relevant respondents. Irrelevant respondents are those who may jeopardize indicators and respondents who are not measured correctly, such as respondents who guess answers can be separated. In this study, only 293 of the 356 respondents were found to meet the person fit index.

\section{Difficulty level of MEQI-C items}

Difficulty level of the item refers to the Person-Item Map. Based on Table 6, the dotted line in the center represented the location of the measurement at the logit scale where the left side of the map showed the order of the individual responses, while the right side of the map showed the order of the items. In this study, the mean value of the individual was higher than the mean value of the item meaning that the MEQI-C questions were appropriate and could be answered by the respondents.

The Person-Item Map also showed the individual and item position as a whole. Individual positions marked as hash tag (\#) represented three students, while point (.) represented a student. Individuals who are above average mean (left) on positive logit values are high-ability individuals, while individuals who are below average mean on negative logit values are low-ability individuals. In this study, there were four students with very high ability and six students with very low ability and seven students were in the mean items.

Subsequently, the items above the average mean (right) are the most difficult item, while items below the average mean are the simplest item. In this study, B4 item of "I can speak in public without feeling nervous" was the most difficult item for respondents to agree. Based on the facial expressions of the three students, they explained that the item made it difficult for them to imagine situations when they were in public. However, the easiest item to accept was B23 item, "I believe God will help diligent people (for example: study, pray etc.)". This item was also an upgraded item. 
INTERNATIONAL JOURNAL OF ACADEMIC RESEARCH IN BUSINESS AND SOCIAL SCIENCES

Vol. 10, No. 4, April, 2020, E-ISSN: 2222-6990 @ 2020 HRMARS

Table 6 Item and individual map of MEQI-C

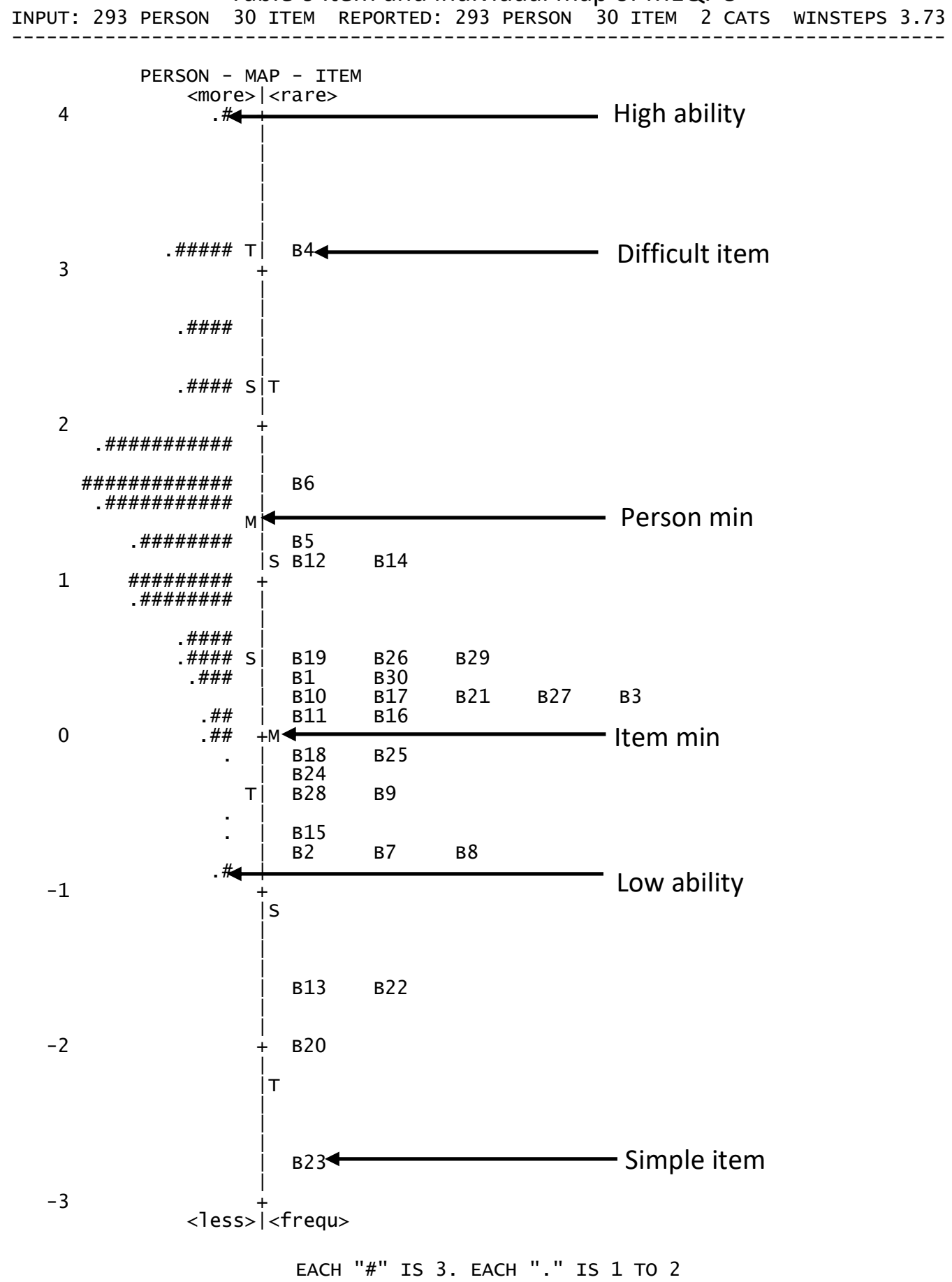

\section{Unidimensionality of MEQI-C}

Table 7 shows the summary of three main features to study the concept of unidimensionality: (i) Principal Component Analysis of Residual (PCA); (ii) degree of interruption of the item in the first contrast; and (iii) Eigen values. 
INTERNATIONAL JOURNAL OF ACADEMIC RESEARCH IN BUSINESS AND SOCIAL SCIENCES Vol. 10, No. 4, April, 2020, E-ISSN: 2222-6990 @ 2020 HRMARS

Table 7 Summary of MEQI-C Unidimensionality Construct Analysis

\begin{tabular}{lccccc}
\hline Subconstruct & $\begin{array}{c}\text { No. of } \\
\text { items }\end{array}$ & $\begin{array}{c}\text { Principal } \\
\text { Component } \\
\text { Analysis (PCA) }\end{array}$ & $\begin{array}{c}\text { Model } \\
\text { Expected } \\
\text { Value }\end{array}$ & $\begin{array}{c}\text { Level of Item } \\
\text { Interruption in } \\
\text { First Contrast }\end{array}$ & $\begin{array}{c}\text { Eigen } \\
\text { Value }\end{array}$ \\
\hline Overall MEQI-C & 30 & $22.2 \%$ & $23.0 \%$ & $5.2 \%$ & 2.0 \\
\hline
\end{tabular}

Based on Table 7, it was found that the overall MEQI-C exceeded the first requirement by more than $20 \%$ as described by Conrad et al. (2012). The PCA value was $22.2 \%$ and very close to the model expected value of $23.0 \%$. It concluded that these constructs were good. For the second condition, the degree of interruption of the item in the first contrast should be below $15 \%$ (Fisher, 2007) which also met the overall MEQI-C. The MEQI-C recorded an interruption rate of items at $5.2 \%$, indicating a low level of interruption.

For the third condition, the overall Eigen value was 2.0. The overall ME was less than five indicating that no second dimension exists (Linacre, 2005). In conclusion, the MEQI-C instrument has achieved unidimensionality as it measured emotional intelligence variables. Findings showed that PCA values were above 20\% (Conrad et al., 2012), item impairment levels were below $15 \%$ (Fisher, 2007) and Eigen values were less than five (Linacre, 2005).

\section{Discussion}

The analysis of Rasch on MEQI-C items indicated that the items have excellent and effective reliability with a high degree of consistency. The reliability of 0.97 was strong to accept as it exceeded 0.80 (Bond \& Fox, 2007). MEQI-C item has consistency when administered repeatedly to other groups of respondents with similar ability but at different times (Creswell, 2017). Based on the item separation index, the value was close to 6 indicating that the MEQI-C items were excellent as they could be distinguished by up to 6 item difficulty levels. In this case, 30 MEQI-C items can be broken down into 6 groups of item strata. These values signified that the items have formed a welldistributed variable and that the item position on the logit scale was highly reliable (Wright \& Masters, 2002). This is because the index value of the item separation exceeded five and categorized as excellent (Fisher, 2007).

Based on individual reliability values, the value of 0.62 indicated that the items were good and acceptable (Bond \& Fox, 2007). The individual separation index is an estimate of the separation according to the level of ability within the measured variable. In this study, the individual separation index for 293 students showed that there was only 1 strata. This finding showed that there was only one strata of individual ability in the sample group and it was indistinguishable because the MEQI-C cannot classify individuals to several stages in the measured construct. This is because they were of the same group and cannot be distinguished in terms of high or low achievement. Therefore, this finding provides new information related to children that their emotional intelligence has not yet grown so well that it should be viewed as an entire construct and overall, rather than as some constructs. It is possible that the child has never been exposed to emotional intelligence competence. This has led to the development of such competencies. 
Individual reliability scores also affected the Cronbach alpha MEQI-C, but the 0.67 value was still good and acceptable (Bond \& Fox, 2007). However, the reliability of an instrument is sufficient to determine the reliability of the item. Therefore, the MEQI-C can be used in the actual study because the reliability of the MEQI-C indicates the adequacy of the item to measure what should be measured.

Items also have high validity when viewed from the polarity aspect of the item. The item polarity of MEQI-C indicates that the correlation values are good and do not conflict with the constructions to be measured. The PTMEA values for all 30 items were positive indicating that the MEQI-C item was accurate for measuring emotional intelligence constructs. Hence, there was no item that needed attention for repair or removal. The item or individual has responded negatively to the emotional intelligence variable because the item depended on the question's intention.

In addition, based on the item and individual suitability index, the index of both MNSQ Infit and MNSQ Outfit is between 0.5 and 1.5 logit (Linacre, 2005). This indicated that 29 out of 30 items (item fit) have measured emotional intelligence constructs and have been retained. Only B23 item was out of range and has been modified. The item modification was intended to fit the Rasch measurement model. In addition, only 293 people out of 356 (person fit) were found to meet the individual fit index. The item and individual suitability index should be considered as it will affect and influence the reliability and validity of the MEQI-C.

Based on the Item-Individual Map, the individual mean value was higher than the item mean value. This indicated that the MEQI-C questions were appropriate and can be answered by the respondents. The item-individual map showed that the MEQI-C conformed to the level of item difficulty and individual ability. For example, the map can show very-high and very-low-abilityindividuals which assist the researcher in identifying students based on their ability to intervene. The map also showed the hardest and simplest items that help the researcher to organize the items based on the difficulty level in the examination paper.

Finally, the MEQI-C has addressed the three main requirements of the concept of unidimensionality. This means that the items in the MEQI-C can be considered as measuring in one direction and in a single capacity (Wright \& Master, 2002). This is because the concept of unidimensionality has focused on one characteristic or dimension at a time (Bond \& Fox, 2015). In fact, this assumption is difficult to fully grasp because there are other unknown and uncontrollable factors that influence an individual's response. For example, motivation, tendency to guess and anxiety are factors that affect individuals and are difficult to determine.

\section{Conclusion}

Based on Rasch model measurements, the functionality of each MEQI-C instrument item can be analyzed in depth to determine its validity and reliability. The analysis of this study showed that (i) the reliability of MEQI-C items was high at 0.97, (ii) all 30 MEQI-C items measured emotional intelligence construct, (iii) 29 items were retained (item fit) and one item was improved, while only 293 persons (person fit) of 356 respondents were involved, (iv) the MEQI-C question was 
INTERNATIONAL JOURNAL OF ACADEMIC RESEARCH IN BUSINESS AND SOCIAL SCIENCES Vol. 10, No. 4, April, 2020, E-ISSN: 2222-6990 @ 2020 HRMARS

appropriate to the individual's ability as the item was answerable to the respondent, and $(\mathrm{v})$ the MEQI-C items reached the concept of single unidimensionality. In conclusion, these five diagnoses have complied with the requirements needed to examine the validity and reliability of the MEQI-C. This study shows that the MEQI-C is valid and reliable for use in field studies.

\section{Acknowledgements}

First and foremost, I am very grateful to National University of Malaysia for supported this project with Universiti Kebangsaan Malaysia grant (GG-2019-025). Besides, my deepest appreciation towards both of my supervisors for helping me during this project. I am thankful to the principal, teachers and students of the project school in Seremban, Negeri Sembilan for their willingness to participate in this project. Lastly, I wish to express my gratitude to my beloved parents and family members for their understanding, encouragement and endless support.

\section{Corresponding Author}

Assoc. Prof. Dr. Salleh Amat

Faculty of Education, National University of Malaysia.

Email : sallehba@ukm.edu.my / sallehamat@gmail.com

\section{References}

Azrilah, A. A., Saidfudin, M., \& Azami Z. (2017). Asas Model Pengukuran Rasch: Pembentukan Skala \& Struktur Pengukuran. Bangi: Fakulti Pendidikan UKM.

Bar-On, R., \& Parker, J. D. A. (2000). The Handbook of Emotional Intelligence: Theory, Development, Assessment and Application at Home, School and In the Workplace. San Francisco: JosseyBass.

Bond, T. G., \& Fox, C. M. (2007). Applying the Rasch Model Fundamental Measurement in the Human Sciences. $2^{\text {nd. }}$ ed. New York: Routledge.

Bond, T. G., \& Fox, C. M. (2015). Applying the Rasch Model Fundamental Measurement in the Human Sciences. $3^{\text {rd. }}$ ed. New York: Routledge.

Cooper, D. R., \& Schindler, P. S. (2011). Business Research Methods. 11th ed. New York: McGrawHill, Irwin.

Conrad, K. M., Conrad, K. J., Dennis, M. L., \& Funk, R. (2012). Validation of the self help improvement scale to the Rasch measurement model GAIN methods report 1.0. Retrieved from http://gaincc.org/_data/files/Psychometrics_and_Publications/

Fisher, J. W. P. (2007). Rating scale instrument quality criteria. Rasch Measurement Transactions 21(1): 1095.

Fraenkel, J. R., Wallen, N. E., \& Hyun, H. H. (2018). How to Design and Evaluate Research in Education. Tenth Edition. New York: Mc Graw Hill.

Goleman, D. (1996). Emotional Intelligence: Why It Can Matter More Than IQ. New York. Bantam Books.

Goleman, D. (1999). Emotional Intelligence: Working With Emotional Intelligence. New York. Bantam Books.

Linacre, J. M. (2005). Standard errors: Means, measures, origins and anchor values. Rasch Measurement Transactions. 19(3): 1030. 
INTERNATIONAL JOURNAL OF ACADEMIC RESEARCH IN BUSINESS AND SOCIAL SCIENCES

Vol. 10, No. 4, April, 2020, E-ISSN: 2222-6990 @ 2020 HRMARS

Noriah, M. I. (2019). Memupuk Kepintaran Pelajar Pintar dan Berbakat: Peranan dan Cabaran Kaunselor. Bangi: Penerbit Universiti Kebangsaan Malaysia.

Richardson, H. R. L. (2015). More than just child's play: Symbolic expressions of illness and spirit. International Journal of Children's Spirituality. 20(2): 100-113. http://eds.a.ebscohost.com.ezplib.ukm.my/

Siti Aishah, H. (2006). Maternal quality time, children's emotional intelligence and their academic performance: A structural equation modelling analysis. Tesis Dr. Fal, Universiti Islam Antarabangsa Malaysia.

Wright, B. D., \& Masters, G. N. (2002). Rating Scale Analysis Rasch Measurement. Chicago: MESA Press. 